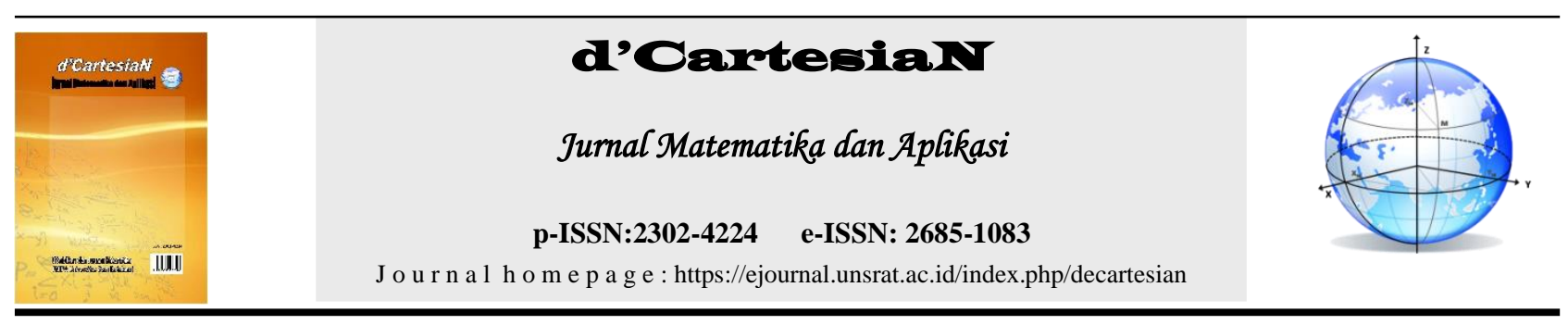

\title{
Estimasi Parameter Copula Plackett Untuk Data Bivariat Melalui Metode Generalized Linear Model Pada Regresi Mediannya
}

\author{
Egidius Saut Poltak Situmorang1, Bambang Susanto' ${ }^{1}$, Leopoldus Ricky Sasongko ${ }^{{ }^{*}}$ \\ ${ }^{1}$ Program Studi Matematika-Fakultas Sains dan Matematika-UKSW, Jln. Diponegoro No. 52-60, Salatiga 50711, Indonesia \\ ${ }^{*}$ Corresponding author: leopoldus.sasongko@uksw.edu
}

\begin{abstract}
A B S T R A K
Hubungan antardua peubah acak dapat dilakukan melalui pendekatan regresi linier. Namun keterbatasan regresi linier dalam pemenuhan asumsi klasik sering menjadi kendala analisis. Keterbatasan ini dapat diatasi dengan melibatkan model distribusi bivariat yang disebut copula pada analisis regresi. Copula memiliki keunggulan salah satunya adalah mampu menunjukkan keterhubungan yang tidak linier. Generalized Linear Model (GLM) adalah bentuk perluasan regresi linier. Diketahui bahwa regresi kuantil pada Copula Plackett merupakan suatu bentuk GLM dengan suatu fungsi invers link $G^{-1}(\cdot)$. Penelitian ini bertujuan untuk menganalisis keterhubungan dua peubah melalui parameter Copula Plackett yang diestimasi melalui pendekatan Generalized Linier Model pada regresi mediannya dengan metode Least Square. Validasi parameter Copula Plackett dilakukan dengan metode simulasi parametric bootstrap melalui pengulangan metode bagi dua. Regresi median terbaik dipilih melalui nilai Mean Square Error terkecil. Perolehan parameter Copula Plackett diterapkan pada data penelitian, yaitu return IHSG dan return kurs beli JPY-IDR untuk menganalisis keterhubungan keduanya. Hasil penelitian menunjukkan bahwa keterhubungan return IHSG dan return kurs beli JPY-IDR dinyatakan ada namun tidak dapat dikatakan saling bebas.
\end{abstract}

\section{INFO ARTIKEL :}

Diterima : 8 April 2020

Diterima setelah revisi : 30 Agustus 2020

Tersedia online : 30 Desmber 2020

\section{Kata Kunci:}

Copula Plackett,

Generalized Linear Model,

Parameter,

Peubah Acak,

Keterhubungan.

\begin{abstract}
A B S T R A C T
The limitations of linear regression in meeting classical assumptions can be overcome by involving copula. Copula can show a non-linear relationship. Generalized Linear Model (GLM) is an extension form of linear regression. It is known that the quantile regression in Copula Plackett is a form of GLM. This study aims to analyze the relationship of two variables through the Copula Plackett parameter which is estimated through the GLM approach on median regression using the Least Square method. Validation of the Copula Plackett parameter is performed by the parametric bootstrap simulation. The best median regression is chosen through the smallest Mean Square Error value. The acquisition of the Copula Plackett parameter is applied to the JCI return and the JPY-IDR buying rates return to analyze the relationship between the two. The results showed that the relationship between them were stated but could not be said to be mutually independent.
\end{abstract}

\section{ARTICLE INFO :}

Received : 8 April 2020

Received in revised form : 30 August 2020

Available online : 30 December 2020

Ke y w o r d s:
Plackett Copula,
Generalized Linear Model,
Parameter,
Random variables
Relationship.

\section{PENDAHULUAN}

Keterhubungan dua peubah acak dapat ditunjukkan melalui analisis regresi, yaitu ekspektasi bersyarat peubah satu terhadap yang lain. Analisis regresi yang biasa digunakan dalam melihat keterhubungan dua peubah acak adalah analisis regresi linier yang hanya mampu menjelaskan bentuk keterhubungan secara linier. Pada analisis regresi linier terdapat syarat yaitu pemenuhan uji asumsi klasik [1]. Tidak jarang dijumpai kendala dalam pemenuhan uji asumsi klasik tersebut, seperti galat model tidak berdistribusi normal atau keterhubungan dua peubah acak tidak linier.

Salah satu usulan disampaikan oleh [2] bahwa dalam menjelaskan keterhubungan antara dua peubah acak dapat digunakan kurva kuantil bersyarat pada model distribusi bivariat yang disebut copula, yang pada penelitiannya disebut sebagai regresi median pada berbagai Copula. Copula itu sendiri tidak ketat pada suatu fungsi distribusi pada setiap peubah acaknya, dapat menjelaskan hubungan secara umum (linier dan nonlinier), dan mudah membangun distribusi gabungan dari peubah-peubah yang berbeda distribusi [3]. Terkhusus pada Copula Plackett, regresi pada kuantil median dengan parameter $\theta$ berbentuk linier [4]. Pada regresi median Copula Plackett, parameter Copula Plackett perlu diestimasi terlebih dahulu hingga didapatkan fungsi distribusi bersyarat satu peubah terhadap yang lain. Kemudian kurva regresinya merupakan suatu fungsi yang merupakan solusi dari fungsi distribusi bersyarat yang disetarakan dengan 0.5 sebagai nilai median. 
Generalized Linear Model (GLM) adalah salah satu bentuk lain dari regresi linier sederhana yang memperluas asumsi bahwa peubah tak bebas dapat berdistribusi yang termasuk dalam anggota keluarga eksponensial. Pada model GLM terdapat tiga komponen utama, salah satunya adalah fungsi link (fungsi penghubung) yang mampu menjelaskan nilai ekspektasi dari peubah tak bebas [5].

Dalam penelitian ini akan dibahas keterhubungan dua peubah yaitu IHSG dan kurs beli mata uang Jepang terhadap Indonesia, dimana sudah dapat dipastikan bahwa data return dari harga saham dan nilai tukar tersebut tidak mengikuti model distribusi bivariat Normal akibat nilai tukar yang mengalami perubahan yang tidak stabil [6]. Hal ini penting karena dalam penelitian ini asumsi model bivariat Normal tidak terpenuhi sehingga digunakan copula sebagai model distribusi bivariatnya.

Mengacu pada [2], didapati bahwa regresi median pada model Copula Plackett merupakan suatu GLM. Pendekatan GLM untuk mengestimasi parameter copula telah dilakukan [7] dengan metode simulasi. Berdasarkan penemuan tersebut, maka hal baru yang akan disampaikan pada penelitian ini adalah pendekatan GLM untuk mengestimasi parameter dan regresi kuantil pada suatu copula, yaitu Copula Plackett yang mampu menjelaskan keterhubungan dua peubah acak, IHSG dan Kurs Beli JPY-IDR.

\subsection{Data Penelitian}

Data penelitian ini adalah data IHSG yang diambil melalui website https://finance.yahoo.com dan Kurs Beli JPY (Japanese Yen) terhadap IDR (Indonesian Rupiah) yang diambil dari website https://bi.go.id. Data yang digunakan adalah data satu tahun, yaitu dari 1 Januari 2018 hingga 31 Desember 2018

\subsection{Transformasi Data}

Perlakuan teknik transformasi data berbeda untuk setiap jenis data, terkhusus pada data keuangan dilakukan transformasi data return [8]. Return merupakan sebuah bentuk tingkat keuntungan yang digunakan pada data saham dan diperoleh berdasarkan selisih data historis (sebelumnya) dengan data yang terjadi setelahnya [9]. Teknik transformasi return dilakukan melalui persamaan berikut [8]

$$
\begin{aligned}
& x_{t}=-\ln \frac{\operatorname{Kurs}_{t}}{\operatorname{KurS}_{t-1}} \\
& y_{t}=\ln \frac{I H S G_{t}}{I H S G_{t-1}}
\end{aligned}
$$

dengan Kurs $_{t}$ adalah harga Kurs Beli JPY-IDR pada waktu $t$, dan $I H S G_{t}$ adalah nilai IHSG pada waktu $t$, sehingga diperoleh data bivariat $\left(x_{t}, y_{t}\right)$.

\subsection{Model Distribusi Univariat Normal}

Fungsi kepadatan probabilitas pada peubah acak yang tersebar dari $-\infty<x<\infty$ yang diberikan distribusi Normal adalah

$$
f(x)=\frac{1}{\sigma \sqrt{2 \pi \sigma^{2}}} \exp -\frac{1}{2}\left(\frac{x-\mu}{\sigma}\right)^{2},-\infty<x<\infty
$$

dengan parameter $\mu$ sebagai rata-rata dan $\sigma^{2}$ sebagai variansinya [10]. Fungsi distribusi Normal dituliskan sebagai:

$$
F_{x}(x)=\frac{1}{\sigma \sqrt{2 \pi}} \int_{-\infty}^{x} \exp \left\{-\frac{1}{2}\left(\frac{t-\mu}{\sigma}\right)^{2}\right\} d t, \quad x \in(0, \infty)
$$

dimana $\mu \in \mathbb{R}$, dan $\sigma^{2}>0$ dengan notasi distribusi Normal $\mathcal{N}\left(\mu, \sigma^{2}\right)$.

\subsection{Model Distribusi Univariat Laplace}

Diberikan model distribusi univariat Laplace dengan persebaran peubah acak yang tersebar pada interval $-\infty<x<\infty$ dengan parameter $x>0$. Fungsi kepadatan probabilitasnya dinyatakan sebagai berikut

$$
f(x)=\frac{1}{2 b} \exp -\frac{|x-\mu|}{b},-\infty<x<\infty
$$

sedangkan fungsi distribusi Laplace didefinisikan sebagai berikut:

$$
F_{x}(x)= \begin{cases}\frac{1}{2} \exp \left(\frac{x-\mu}{b}\right), & x \in(-\infty, a] \\ 1-\frac{1}{2} \exp \left(-\frac{x-\mu}{b}\right), & x \in[a, \infty)\end{cases}
$$

dengan parameter distribusi Laplace $\mu$ dan $b$ dapat dinotasikan sebagai $L(\mu, b)$. Berdasarkan [11], jika terdapat peubah acak $X$ berdistribusi Laplace dengan parameter distribusi $\mu$ dan $b$, maka $|X-\mu|$ berdistribusi eksponensial dengan parameter $\frac{1}{b}$.

\subsection{Uji Kecocokan Distribusi}

Uji kecocokan distribusi dilakukan untuk mengukur kecocokan dari suatu data terhadap distribusi teoritis tertentu. Uji kecocokan distribusi pada penelitian ini dilakukan dengan tiga metode yaitu uji Cramér von Misses, Anderson-Darling, dan Kolmogorov-Smirnov. Langkah awal melakukan uji kecocokan distribusi ini adalah menyusun hipotesis sebagai berikut

$H_{0}$ : data mengikuti distribusi parametrik $F^{*}(x)$

$H_{1}$ : data tidak mengikuti distribusi parametrik $F^{*}(x)$

\subsubsection{Uji Cramér von Misses}

Statistik uji Cramér von Misses didefinisikan sebagai berikut:

$$
C M=n \cdot \int_{-\infty}^{\infty}\left(\hat{F}(x)-F^{*}(x)\right)^{2} f^{*}(x) d x
$$

dengan $\hat{F}(x)$ merupakan fungsi distribusi empiris data dan $F^{*}(x)$ sebagai fungsi distribusi teoritis yang dujikan. Berdasarkan [12] persamaan (3) dapat ditulis menjadi:

$$
C M=\frac{1}{12 n}+\sum_{i=n}^{n}\left[F^{*}\left(x_{i}\right)-\frac{2 i-1}{2 n}\right]^{2}
$$

$H_{0}$ ditolak jika $C M \geq c_{1-\alpha}$. Nilai kritis $c_{1-\alpha}$ dapat dilihat di [13].

\subsubsection{Uji Anderson-Darling}

Uji Anderson dan Darling merupakan modifikasi dari uji Cramér von Misses yang statistik ujinya didefinisikan sebagi berikut: 


$$
A^{2}=-\frac{1}{n}\left[\sum_{j=i}^{n}(2 j-1)\left\{\log \left[F^{*}\left(x_{(j)}\right)\right]+\log \left[1-F^{*}\left(x_{(n+1-j)}\right)\right]\right\}\right]-n(5)
$$

Setelah diperoleh nilai statistik uji $A^{2}$ nilai tersebut dibandingkan dengan nilai kritis, yaitu 1.933, 2.492, dan 3.857 untuk taraf signifikansi $\alpha=0.1,0.05,0.01$. Jika $A^{2}$ lebih dari nilai kritis maka $H_{0}$ ditolak [14].

\subsubsection{Uji Kolmogorov-Smirnov}

Uji Kolmogorov-Smirnov merupakan uji kecocokan distribusi yang didasarkan pada perbedaan fungsi distribusi empiris data $\hat{F}(x)$ dengan fungsi distribusi teoritis $F^{*}(x)$, yang statistik ujinya didefinisikan:

$$
D=\max _{x_{(1)} \leq x \leq x_{(n)}}\left|\hat{F}(x)-F^{*}(x)\right|
$$

dengan nilai dari $x_{(1)}$ dan $x_{(n)}$ merupakan nilai minimum dan maksimum dari tiap data pengamatan. Berdasarkan [14], persamaan (6) dapat ditulis menjadi

$$
D=\max _{i \in\{1, ., n\}}\left\{\max \left\{\left|\frac{i-1}{n}-F^{*}\left(x_{(i)}\right)\right|,\left|\frac{i}{n}-F^{*}\left(x_{(i)}\right)\right|\right\}\right\}
$$

dimana marginal data yang dibangkitkan merupakan data yang urut mulai dari yang terkecil $x_{i}, i=1,2, \ldots, n$. Penarikan kesimpulan dilakukan berdasarkan statistik $D$. Jika nilai $D$ memiliki nilai yang lebih besar dari batas statistik $D_{\alpha}$ dengan nilai $\alpha=0.10,0.05,0.01$ yang nilainya adalah $\frac{1.22}{\sqrt{n}}, \frac{1.36}{\sqrt{n}}, \frac{1.63}{\sqrt{n}}$, maka $H_{0}$ ditolak. Penarikan simpulan juga dapat berdasarkan $P_{\text {value }}$, yaitu jika $P_{\text {value }}>\alpha$, maka $H_{0}$ diterima.

\subsection{Ukuran Keterhubungan Spearman's rho}

Secara umum ukuran keterhubungan Spearman's rho didefiniskan sebagai berikut:

$$
\rho=1-\frac{6 \sum d_{i}^{2}}{n\left(n^{2}-1\right)}
$$

dengan $\sum d_{i}^{2}$ merupakan total selisih antar peringkat data yang ditulis $d_{i}=\operatorname{rank}\left(x_{i}\right)-\operatorname{rank}\left(y_{i}\right), n$ merupakan jumlah sampel penelitiannya dan $-1 \leq \rho \leq 1$.

\subsection{Ukuran Keterhubungan Pearson}

Koefisien korelasi untuk populasi dari Pearson merupakan $\rho$ didefinisikan sebagai berikut:

$$
\rho=\frac{\sigma_{X Y}}{\sqrt{\sigma_{X X} \sigma_{Y Y}}}
$$

dengan $\sigma_{X Y}=E[X Y]-E[X] E[Y], \sigma_{X X}=E[X]^{2}-[E[X]]^{2}$, $\operatorname{dan} \sigma_{Y Y}=E[Y]^{2}-[E[Y]]^{2}$.

\subsection{Copula Bivariat}

Berdasarkan Teorema Sklar yang mengatakan bahwa dimisalkan $H$ merupakan suatu fungsi distribusi bivariat dari masing-masing distribusi peubah acak $F$ dan $G$, maka dalam fungsi distribusi bivariat tersebut juga terdapat copula untuk setiap peubah acak $x, y$ yang dapat dinyatakan sebagai berikut

$$
H(x, y)=C(F(x), G(y))
$$

Fungsi Densitas Copula dinyatakan oleh

$$
h(x, y)=c(F(x), G(y)) f(x) g(y)
$$

dengan $f(x)=\partial F(x) / \partial x$ dan $\quad g(x)=\partial G(y) / \partial y$ berurutan adalah fungsi densitas dari peubah acak $X$ dan $Y$, menurut [4]. Selanjutnya, akan dijelaskan hubungan fungsi densitas peluang bersyarat, fungsi distribusi bersyarat, dan ekspektasi bersyarat untuk data bivariat dengan Copula disebut sebagai properti bersyarat copula.

Fungsi densitas peluang $Y=y$ bersyarat $X=x$, yaitu $k(y \mid x)$ dan kaitannya dengan copula adalah

$$
\begin{aligned}
k(y \mid x) & =\operatorname{Pr}[Y=y \mid X=x]=\frac{\operatorname{Pr}[X=x, Y=y]}{\operatorname{Pr}[X=x]} \\
& =\frac{c(F(x), G(y)) f(x) g(y)}{f(x)} \\
& =c(F(x), G(y)) g(y)
\end{aligned}
$$

Fungsi distribusi $Y$ bersyarat $X=x$ yaitu $K(y \mid x)$ dan dalam kaitannya dengan copula diperoleh dari

$$
\begin{aligned}
K(y \mid x) & =\operatorname{Pr}[Y \leq y \mid X=x]=\int_{0}^{y} k(s \mid x) d s \\
& =\int_{0}^{y} c(F(x), G(s)) g(s) d s \\
& =\int_{0}^{G(y)} \frac{\partial^{2} C(F(x), q)}{\partial F(x) \partial q} d q \\
& =\frac{\partial C(F(x), G(y))}{\partial F(x)}
\end{aligned}
$$

Oleh karena itu, ekspektasi peubah acak $Y$ bersyarat $X=$ $x$ dengan copula dapat ditulis menjadi,

$$
E[Y \mid X=x]=\int_{0}^{\infty} y k(y \mid x) d y=\int_{0}^{\infty} y c(F(x), G(y)) g(y) d y(14)
$$

\subsection{Regresi Median}

Regresi median adalah salah satu regresi kuantil yang mana kuantil yang digunakan adalah kuantil median [4]. Misalkan $\hat{y}_{\alpha}(x)$ adalah solusi dari penyelesaian pada persamaan $K(y \mid x)=\operatorname{Pr}[Y \leq y \mid X=x]$ yang disetarakan dengan $\alpha=0.5$ maka $\hat{y}_{\alpha}(x)$ adalah kurva kuantil median atau regresi kuantil median.

\subsection{Uji Kecocokan Copula}

Tujuan dilakukannya uji kecocokan copula adalah untuk melihat seberapa baik copula dalam memodelkan atau mencerminkan perilaku data. Pada penelitiannya, [4] menggunakan ukuran Cramér von Misses sebagai ukuran kecocokan copula, yang didefinisikan sebagai berikut

$$
S_{n}=\frac{1}{n} \sum_{i=1}^{n}\left[\mathrm{e}\left(x_{i}, y_{i}\right)\right]^{2}=\sum_{i=1}^{n}\left[H_{e}\left(x_{i}, y_{i}\right)-H_{\widehat{\varphi}}\left(x_{i}, y_{i}\right)\right]^{2}(15)
$$

dengan $H_{e}\left(x_{i}, y_{i}\right)=C_{e}\left(F\left(x_{i}\right), G\left(y_{i}\right)\right)=\frac{\#\left(x \leq x_{i}, y \leq y_{i}\right)}{n+1}$ merupakan fungsi distribusi bivariat empirik untuk data $\left\{\left(x_{i}, y_{i}\right), \ldots,\left(x_{n}, y_{n}\right)\right\}$ dan $\#\left(x \leq x_{i}, y \leq y_{i}\right)$ menyatakan banyaknya data bivariat $\{(x, y)\}$ dimana $x \leq x_{i}, y \leq y_{i}$.

Uji kecocokan yang didasarkan pada statistik Cramér von Misses pada fungsi distribusi bivariat tersebut, ditentukan pada nilai $S_{n}$ terkecil dari fungsi copula yang dicocokan. Dapat pula dilihat melalui $P_{\text {value }}$ yang diperoleh melalui parametric bootstrap yang disarankan oleh [15]. 


\subsection{Pembangkitan Bilangan Acak Bivariat Menggunakan Copula}

Pembangkitan data bivariat $\{(x, y)\}$ dari fungsi distribusi bivariat $H$ menggunakan copula dilakukan dengan memperhatikan persamaan (13). Misalkan $\frac{\partial C(u, v)}{\partial u}$ adalah fungsi dalam $v$, dengan $u=F(x)$ dan $v=$ $G(y)$, sehingga

$$
Z_{u}=\frac{\partial C(u, v)}{\partial u}
$$

Langkah-langkah pembangkitan data bivariat $\{(x, y)\}$ sebagai berikut [4]

1. Bangkitkan dua bilangan acak saling bebas $u$ dan $t$, distribusi seragam di [0,1];

2. Dapatkan $v=Z_{u}{ }^{(-1)}(t)$, dimana $Z_{u}{ }^{(-1)}$ adalah invers fungsi $Z_{u}$;

3. Dapatkan sepasang bilangan acak bivariat dari suatu copula yaitu $(u, v)$;

4. Dapatkan sepasang bilangan acak bivariat $(x, y)=$ $\left(F^{-1}(u), G^{-1}(v)\right)$

\subsection{Ukuran Statistik Cramér von Misses dengan Parametric Bootstrap}

Ukuran statistik $\left(S_{n}\right)$ dan $P_{\text {value }}$ Cramér von Misses dapat diperoleh melalui bantuan simulasi parametric bootstrap. Algoritma simulasi parametric bootstrap tersebut dijabarkan sebagai berikut:

Diketahui data bivariat sebanyak $n$ pasang yaitu $\left\{\left(x_{a}, y_{a}\right)\right\}, a=1,2,3, \ldots n$. Untuk $N$ bilangan bulat positif sangat besar,

1. Bangkitkan sampel acak bivariat $\left\{\left(x_{i}, y_{i}\right)\right\}, i=$ $1,2,3 \ldots n$, dari suatu distribusi bivariat $H_{\theta}(x, y)$ atau Copula $C_{\theta}(F(x), G(y))$.

2. Hitung $H_{e}\left(x_{1}, y_{1}\right)=C_{e}\left(F\left(x_{i}\right), G\left(y_{i}\right)\right)=\frac{\#\left(x_{a} \leq x_{i}, y_{a} \leq y_{i}\right)}{n+1}$ yang mana \# $\left(x_{a} \leq x_{i}, y_{a} \leq y_{i}\right)$ menyatakan banyak data bivariat $\left\{\left(x_{a}, y_{a}\right)\right\}$ dengan $x_{a} \leq x_{i}$ dan $y_{a} \leq y_{i}$,

3. Untuk $j=1$, hitung

$$
\begin{aligned}
s_{n, j}^{*} & =\sum_{i=1}^{n}\left[H_{e}\left(x_{i}, y_{i}\right)-H_{\theta}\left(x_{i}, y_{i}\right)\right]^{2} \\
& =\sum_{i=1}^{n}\left[C_{e}\left(F\left(x_{i}\right), G\left(y_{i}\right)\right)-C_{\theta}\left(F\left(x_{i}\right), G\left(y_{i}\right)\right)\right]^{2}
\end{aligned}
$$

4. Untuk $j=j+1$, ulangi poin 1 sampai poin 3 , ke poin 5 jika $j=N+1$,

5. Hitung $p$-value yaitu $\frac{\#\left(s_{n, j}^{*}>s_{n}\right)}{N}$ atau $\sum_{j=1}^{N}\left(\frac{I\left(s_{n, j}^{*}>s_{n}\right)}{N}\right)$, yang mana $I\left(s_{n, j}^{*}>s_{n}\right)$ adalah fungsi bernilai 1 untuk $s_{n, j}^{*}>s_{n}$.

\subsection{Copula Plackett}

Copula Plackett memiliki bentuk umum yang dapat didefinisikan sebagai berikut (16)

$C_{P, \theta}(u, v)=\frac{[1+(\theta-1)(u+v)]-\sqrt{[1+(\theta-1)(u+v)]^{2}-4 u v \theta(\theta-1)}}{2(\theta-1)}(16)$ dengan $\theta \neq 1$ dan berada pada interval $(0, \infty)$. Ketika $\theta=1, C_{P, 1}(u, v)=u v$.

Properti bersyarat Copula Plackett didefinisikan sebagai berikut

$$
\frac{\partial C_{P, \theta}(u v)}{\partial u}=\frac{\theta v+(1-\theta) C(u, v)}{1+(\theta-1)[u+v-2 C(u, v)]}
$$

saat $0<\theta<\infty$ dan $\theta \neq 1$. Saat $\theta=1, \frac{\partial C_{P, \theta}(u v)}{\partial u}=v$.

Berdasarkan (16) diperoleh Spearman's rho melalui Copula Plackett dinyatakan oleh

$$
\rho=\frac{\theta+1}{\theta-1}-\frac{2 \theta}{(\theta-1)^{2}} \ln \theta, \quad \theta \neq-1,1
$$

Regresi Median pada Copula Plackett merupakan regresi kuantil $\alpha$, dimana $\alpha=0,5$. Regresi median pada Copula Plackett merupakan fungsi linier $\hat{v}$ yang merupakan solusi dari persamaan (16) yang disetarakan $\alpha=0,5$ sehingga diperoleh

$$
v=\frac{1}{\theta+1}+\frac{\theta-1}{\theta+1} u, \theta \neq-1,1
$$

Oleh karena $u=F(x)$ dan $v=G(y)$, maka $y=G^{-1}(v)$ maka regresi median dalam bentuk $\hat{y}(x)$ dapat ditulis sebagai berikut

$$
\begin{aligned}
\hat{y}(x) & =G^{-1}(\hat{v}(F(x))) \\
& =G^{-1}\left(\frac{1}{1+\theta}+\frac{(\theta-1)}{1+\theta} F(x)\right)
\end{aligned}
$$

\subsection{Generalized Linear Model (GLM)}

GLM merupakan bentuk perluasan dari regresi linier klasik yang memiliki komponen utama sebagai berikut:

1. Random Component, yaitu setiap nilai analisis variabel dependen $Y$ berdistribusi tertentu dan saling bebas.

2. Systematic Component, yaitu kombinasi secara linier antara variabel $X$ dengan parameter $\beta$, secara matematis $\eta=X \beta$.

3. Link function, merupakan fungsi yang menggambarkan nilai ekspektasi setiap variabel dependen $(Y)$ yang dihubungkan dengan variabel penjelas melalui regresi linier, melalui persamaan $g[E(y)]=\boldsymbol{X} \boldsymbol{\beta}$

\section{GLM pada Regresi Kuantil Copula Plackett}

Persamaan (20) adalah suatu GLMl terhadap $u=F(x)$ yaitu

$$
\hat{y}(x)=G^{-1}(a+b u)
$$

dengan $a=1 /(\theta+1)$ dan $b=(\theta-1) /(\theta+1)$. Dalam arti lain, kurva $\hat{y}(x)$ adalah GLM terhadap $u=F(x)$ dengan fungsi invers link $G^{-1}(\cdot)$. Estimasi GLM itu dapat dilakukan dengan bantuan metode Least Square dengan memperhatikan transformasi peubah acak $X$ terhadap $F$ menjadi $U$ dan $Y$ terhadap $G$ menjadi $V$ seperti pada (19) sehingga dapat diperoleh parameter $\theta=(1-a) / a$ (parameter Copula Plackett) dan sekaligus diperoleh regresi mediannya.

\subsection{Penentuan Regresi Median Terbaik}

Penelitian ini menggunakan ukuran MSE (Mean Square Error) untuk menentukan model regresi median terbaik. MSE merupakan rata-rata dari galat model dapat menjadi acuan pemilihan model terbaik, yaitu 


\section{Estimasi Parameter Copula Plackett Untuk Data Bivariat Melalui Metode Generalized Linear Model \\ Pada Regresi Mediannya}

d'Cartesian: Jurnal Matematika dan Aplikasi, Vol. 9, No. 2 (September 2020): 105-112

model regresi terbaik dilihat dari nilai MSE terkecil Secara umum, MSE didefinisikan sebagai berikut

$$
\operatorname{MSE}(\hat{y})=\frac{1}{n} \sum_{i=1}^{n}\left(\hat{y}_{t}-y_{t}\right)^{2}
$$

dimana $\hat{y}_{t}$ adalah nilai ekspektasi dari regresi median, $y_{t}$ adalah data aktual pada waktu $t$ dan $n$ adalah banyaknya data.

\subsection{Metode Bagi Dua}

Metode bagi dua digunakan dalam uji kecocokan Copula Plackett. Metode bagi dua dapat dilakukan dengan mengikuti algoritma berikut ini [17]:

1. Pastikan bahwa $f(a) . f(b)<0$. Jika $a$ dan $b$ tidak memenuhi maka pilih $a$ dan $b$ baru yang memenuhi

2. Pertama lakukan perhitungan titik tengah $c=\frac{a+b}{2}$

3. Menentukan subinterval yang mengurung akar:
a. Jika $f(a) . f(c)<0$, maka $b:=c$, perhitungan ke langkah 4
b. Jika $f(a) \cdot f(c)>0$, maka $a:=c$, perhitungan ke langkah 4
c. Jika $f(a) \cdot f(c)=0$, maka akar persamaan diperoleh $c$. Perhitungan selesai

4. Dihitung mencari akar baru $c=\frac{a+b}{2}$

5. Pengulangan dilakukan pada langkah 1 sampai langkah 3 sedemikian sehingga $f(c) \approx 0$.

\section{Metode Penelitian}

Penelitian ini diawali dengan melakukan pengolahan data, yaitu data IHSG dan Kurs Beli JPYIDR yang ditransformasi return. Teknik transformasi dilakukan berdasarkan persamaan (1) dan (2) sehingga diperoleh pasangan data bivariat $\left(x_{t}, y_{t}\right)$. Selanjutnya melakukan analisis data marginal dengan langkahlangkah sebagai berikut:

1. Melakukan analisis statistik deskriptif dari $x_{t}$ dan $y_{t}$ guna mengetahui karakteristik data.

2. Mengukur keterhubungan data bivariat $\left(x_{t}, y_{t}\right)$ dengan korelasi Pearson dan Spearman's rho.

3. Uji kecocokan distribusi masing masing marginal data. Uji distribusi yang digunakan merupakan uji Cramér von Mises, Anderson-Darling, dan Kolmogorov-Smirnov.

Selanjutnya dilakukan analisis lanjutan untuk data bivariat dengan langkah-langkah berikut:

1. Estimasi parameter Copula Plackett $\theta$ melalui GLM dengan metode Least Square dengan mencari solusi persamaan (21). Estimasi parameter dilakukan untuk semua kombinasi marginal $x_{t}=$ Normal, Laplace dan $y_{t}=$ Normal, Laplace.

2. Menentukan regresi median terbaik dengan menghitung nilai MSE sesuai persamaan (22). Regresi median terbaik dipilih berdasarkan nilai MSE terkecil.
3. Menghitung statistik uji Cramér von Mises untuk menguji kecocokan Copula Plackett dan mencari $P_{\text {value }}$ melalui simulasi parametric bootstrap.

4. Melakukan validasi parameter Copula Plackett dengan langkah sebagai berikut

i. Bangkitkan sepasang bilangan acak bivariat dari Copula Plackett, yaitu $(u, v)$ sebanyak $k$, untuk $k$ adalah ukuran sampel data penelitian $\left(x_{t}, y_{t}\right)$;

ii. Dapatkan sepasang bilangan acak bivariat $(x, y)=\left(F^{-1}(u), G^{-1}(v)\right)$

iii. Peroleh fungsi distribusi empirik dari masing-masing $x$ dan $y$;

iv. Hitung parameter $\rho$ melalui korelasi Spearman's rho dari $(x, y)$ berdasarkan persamaan (16) dan melalui Metode Bagi Dua dilakukan estimasi parameter Copula Plackett $\theta$;

v. Validasi parameter Copula Plackett untuk masing-masing model dilakukan berdasarkan $P_{\text {value }}$ yang diperoleh dari pengulangan langkah i-iv sebanyak 100 kali melalui simulasi parametric bootstrap.

\section{Hasil dan Pembahasan \\ 3.1. Data Marginal}

Data bivariat $\left(x_{t}, y_{t}\right)$ yang telah ditransformasi return melalui persamaan (1) dan (2) digambarkan sebagai berikut:

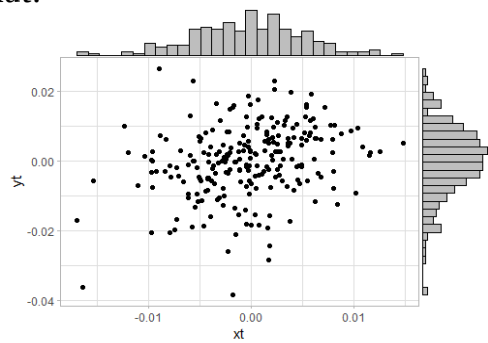

Gambar 1. Scatterhist data $\left(x_{t}, y_{t}\right)$

Analisis statistik deskriptif ditampilkan dalam Tabel 1.

Tabel 1. Statistik Deskriptif Data Marginal $x_{t}$ dan $y_{t}$

\begin{tabular}{ccccccc}
\hline & Min & $Q_{1}$ & Median & Mean & $Q_{1}$ & Max \\
\hline$x_{t}$ & -0.0170 & 0.0057 & -0.0003 & -0.0004 & 0.0032 & 0.0180 \\
\hline$y_{t}$ & -0.0383 & -0.0056 & 0.0006 & -0.0001 & 0.0065 & 0.0263 \\
\hline
\end{tabular}

Untuk mengukur arah dan besaran hubungan antar data, digunakan ukuran keterhubungan Spearman's rho dan Pearson. Hasil ukuran keterhubungannya disajikan pada Tabel 2.

Tabel 2. Ukuran keterhubungan Spearman's rho dan Pearson

\begin{tabular}{ccc}
\hline \multirow{2}{*}{ Sampel Bivariat } & \multicolumn{2}{c}{ Ukuran Keterhubungan } \\
\cline { 2 - 3 } & Pearson $(\hat{\rho})$ & Spearman $\left(\hat{\rho}_{s}\right)$ \\
\hline x dan y & 0.2792153 & 0.3101223 \\
\hline
\end{tabular}




\subsection{Uji Kecocokan Distribusi}

Uji kecocokan distribusi dilakukan untuk masingmasing peubah acak $x_{t}$ dan $y_{t}$ dengan asumsi kedua marginal data mengikuti distribusi Normal dan Laplace. Kedua distribusi tersebut dipilih karena termasuk ke dalam keluarga eksponensial yang merupakan syarat perlu pendekatan GLM. Maka dipilih uji AndersonDarling, Cramér-von Mises, dan Kolmogorov-Smirnov. Hasil uji kecocokan distribusi dan estimasi parameter ditampilkan dalam Tabel 3 .

Tabel 3. Estimasi Parameter Distribusi Marginal dan Uji Kecocokan Distribusi

\begin{tabular}{|c|c|c|}
\hline Distribusi & Normal & Laplace \\
\hline Peubah acak & \multicolumn{2}{|c|}{$x_{t}$} \\
\hline \multirow{2}{*}{ Parameter } & $\mu=-0.000378$ & $\mu=-0.00038$ \\
\hline & $\sigma=0.005339$ & $\lambda=0.004193$ \\
\hline Uji Distribusi & \multicolumn{2}{|c|}{$p-$ value } \\
\hline Anderson-Darling & 0.9946 & 0.306 \\
\hline $\begin{array}{l}\text { Cramér von } \\
\quad \text { Misses }\end{array}$ & 0.994 & 0.3014 \\
\hline $\begin{array}{l}\text { Kolmogorov- } \\
\text { Smirnov }\end{array}$ & 0.9654 & 0.362 \\
\hline Distribusi & Normal & Laplace \\
\hline Peubah acak & \multicolumn{2}{|c|}{$y_{t}$} \\
\hline \multirow{2}{*}{ Parameter } & $\mu=-0.0001$ & $\mu=-0.000563$ \\
\hline & $\sigma=0.0102$ & $\lambda=0.007788$ \\
\hline Uji Distribusi & \multicolumn{2}{|c|}{$p-$ value } \\
\hline Anderson-Darling & 0.358 & 0.4555 \\
\hline $\begin{array}{l}\text { Cramér von } \\
\text { Misses }\end{array}$ & 0.364 & 0.5106 \\
\hline $\begin{array}{l}\text { Kolmogorov- } \\
\text { Smirnov }\end{array}$ & 0.446 & 0.7571 \\
\hline
\end{tabular}

Berdasarkan $P_{\text {value }}$ yang diberikan Tabel 3, dapat diambil kesimpulan bahwa kedua peubah $x_{t}$ dan $y_{t}$ memenuhi asumsi distribusi Normal dan Laplace. Oleh karena itu, masing-masing peubah $x_{t}$ dan $y_{t}$ memiliki dua kemungkinan distribusi, yaitu masing-masing memiliki kemungkinan berdistribusi Normal dan Laplace.

\subsection{Estimasi Parameter Copula Plackett}

Parameter Copula Plackett diestimasi untuk kombinasi marginal, yaitu marginal $x$ : Normal dan Laplace dan marginal $y$ : Normal dan Laplace. Estimasi parameter Copula Plackett bertujuan untuk mengidentifikasi keterhubungan antarpeubah. Tabel 4 menyajikan hasil estimasi parameter Copula Plackett melalui GLM dengan metode least square dari masingmasing kombinasi distribusi, dengan Model 1: $x_{t} \sim$ Normal dan $y_{t} \sim$ Normal, Model 2: $x_{t} \sim$ Normal dan $y_{t} \sim$ Laplace, Model 3: $x_{t} \sim$ Laplace dan $y_{t} \sim$ Normal, dan Model 4: $x_{t} \sim$ Laplace dan $y_{t} \sim$ Laplace.

Tabel 4. Estimasi Parameter Copula Plackett

\begin{tabular}{cccc}
\hline \multirow{2}{*}{ Model } & \multicolumn{2}{c}{ Distribusi } & $\theta$ \\
\cline { 2 - 3 } & $x_{t}$ & $y_{t}$ & \\
\hline Model 1 & Normal & Normal & 1.762482 \\
Model 2 & Normal & Laplace & $\mathbf{2 . 0 1 6 8 4 3}$ \\
Model 3 & Laplace & Normal & 1.708664 \\
Model 4 & Laplace & Laplace & 1.947532 \\
\hline
\end{tabular}

\subsection{Uji Kecocokan Data Bivariat Terhadap Copula Plackett}

Setelah diperoleh estimasi parameter Copula Plackett, dilakukan uji kecocokan copula. Uji kecocokan data bivariat terhadap model distribusi bivariat atau copula perlu dilakukan untuk melihat seberapa cocok copula dalam mencerminkan perilaku data. Uji ini dilakukan dengan menghitung statistik Cramér-von Mises $S_{n}$, kemudian mencari $P_{\text {value }}$ melalui simulasi parametric bootstrap. Hasil perolehan nilai $S_{n}$ dan $P_{\text {value }}$ ditunjukkan pada Tabel 5 .

Tabel 5. Hasil Uji Kecocokan Copula Plackett

\begin{tabular}{ccccc}
\hline \multirow{2}{*}{ Model } & \multicolumn{2}{c}{ Distribusi } & \multirow{2}{*}{$S_{n}$} & $P_{\text {value }}$ \\
\cline { 2 - 3 } & $X$ & $Y$ & & \\
\hline 1 & Normal & Normal & 0.05890675 & 0.292 \\
2 & Normal & Laplace & 0.06643332 & 0.011 \\
3 & Laplace & Normal & 0.1201998 & 0.37 \\
4 & Laplace & Laplace & 0.1371124 & 0.084 \\
\hline
\end{tabular}

Berdasarkan Tabel 5, $P_{\text {value }}$ tertinggi dimiliki oleh Model 3 dengan kombinasi marginal $x \sim$ Laplace dan $y \sim$ Normal. Artinya bahwa Copula Plackett paling cocok menggambarkan perilaku data Model 3 dibandingkan dengan model lainnya.

\subsection{Analisis Regresi Median}

Seperti pada penelitian [18], setelah uji kecocokan Copula Plackett dilakukan analisis regresi median untuk setiap alternatif marginal. Analisis regresi median dilakukan dengan menghitung nilai MSE untuk menentukan regresi median terbaik. Hasil perhitungan MSE untuk setiap alternatif marginal disajikan pada Tabel 6.

Tabel 6. Nilai MSE Setiap Alternatif Marginal

\begin{tabular}{cccc}
\hline \multirow{2}{*}{ Model } & \multicolumn{2}{c}{ Distribusi } & \multirow{2}{*}{ MSE } \\
\hline Model 1 & $x_{t}$ & $y_{t}$ & \\
Model 2 & Normal & Normal & $9.634401 \times 10^{-5}$ \\
Model 3 & Laplace & Normal & $9.757253 \times 10^{-5}$ \\
Model 4 & Laplace & Laplace & $9.627478 \times 10^{-5}$ \\
\hline
\end{tabular}

Pada Tabel 6, dapat dilihat bahwa Model 3 menunjukkan nilai MSE terkecil dari ketiga model lainnya dengan kurva regresi sebagai ditampilkan pada Gambar 2.

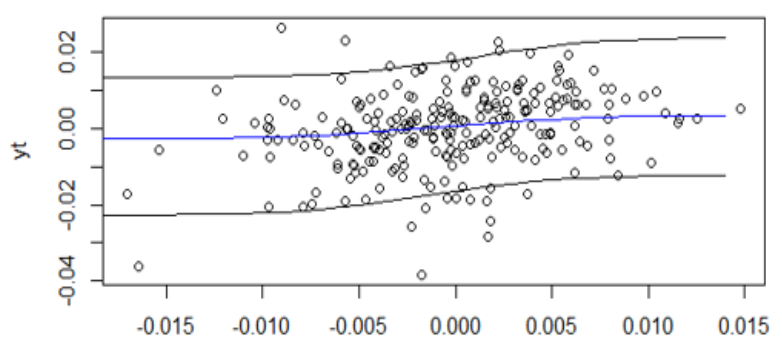
$x t$

Gambar 2. Kurva regresi pada kombinasi distribusi $x_{t} \sim$ Laplace dan $y_{t} \sim$ Normal

Berdasarkan hasil uji kecocokan Copula Plackett dan analisis regresi median, dapat dikatakan bahwa 


\section{Estimasi Parameter Copula Plackett Untuk Data Bivariat Melalui Metode Generalized Linear Model \\ Pada Regresi Mediannya}

d'Cartesian: Jurnal Matematika dan Aplikasi, Vol. 9, No. 2 (September 2020): 105-112

model terbaik adalah Model 3 dengan kombinasi marginal $x \sim$ Laplace dan $y \sim$ Normal.

\subsection{Validasi Parameter Copula Plackett}

Validasi parameter Copula Plackett yang diperoleh melalui metode Least Square dilakukan dengan bantuan simulasi parametric bootstrap. Parameter Copula Plackett diestimasi melalui korelasi Spearman's rho, dan untuk memperoleh $P_{\text {value }}$, dilakukan pembangkitan parameter Copula Plackett sebanyak 1000 dan diulang sebanyak 100 kali. Perolehan $P_{\text {value }}$ untuk validasi parameter Copula Plackett dapat dilihat pada Tabel 7.

Tabel 7. Perolehan $P_{\text {value }}$ Hasil Simulasi

\begin{tabular}{cccc}
\multirow{2}{*}{ Model } & \multicolumn{2}{c}{ Distribusi } & $P_{\text {value }}$ \\
& $X$ & $Y$ & simulasi \\
\hline 1 & Normal & Normal & 0.00384 \\
2 & Normal & Laplace & 0.00034 \\
3 & Laplace & Normal & 0.00628 \\
4 & Laplace & Laplace & 0.0006 \\
\hline
\end{tabular}

Tabel 7 menunjukkan $P_{\text {value }}$ yang diberikan melalui simulasi parametric bootstrap bernilai dekat ke 0 . Pada tingkat signifikansi $\alpha=0.05$, dapat disimpulkan bahwa parameter Copula Plackett yang diperoleh tidak signifikan terhadap 1. Artinya terdapat keterhubungan antara dua peubah, yakni $x_{t}$ dan $y_{t}$.

\section{KESIMPULAN}

Penelitian ini membuktikan bahwa regresi median Copula dapat digunakan untuk menjelaskan keterhubungan IHSG dan Kurs Beli JPY-IDR. Estimasi parameter yang diperoleh oleh Copula Plackett melalui metode Least Square yang digunakan pada persamaan regresi median Copula Plackett merupakan GLM yang didekatkan melalui fungsi invers link $G^{-1}(\cdot)$. Melalui fungsi tersebut pula diperoleh regresi median dalam $\left(x_{t}, y_{t}\right)$ yang menunjukkan ketidaklinieran. Berdasarkan nilai $P_{\text {value }}$ dari hasil validasi parameter bootstrap dan perhitungan MSE, IHSG dan kurs beli JPY-IDR secara berurutan berdistribusi univariat Laplace dan Normal dengan parameter keterhubungan copula Plackett $\theta=$ 1.708664. Oleh karena nilai parameter copula Plackett $(\theta)$ yang tidak signifikan terhadap 1, maka keterhubungan IHSG dan kurs beli JPY-IDR dinyatakan ada akan tetapi tidak dapat dikatakan saling bebas.

\section{DAFTAR PUSTAKA}

[1] I. A. P. Uthami, I. K. G. Sukarsa, and I. P. E. N. Kencana, "Regresi Kuantil Median Untuk Mengatasi Heteroskedastisitas Pada Analisis Regresi," E-Jurnal Mat., vol. 2, no. 1, pp. 6-13, 2013.

[2] G. A. Rinadi, L. R. Sasongko, and B. Susanto, "Regresi Median Pada Copula Bivariat," JTAM | J. Teor. dan Apl. Mat., vol. 3, no. 1, pp. 07-14, 2019.
[3] C. Schölzel and P. Friederichs, "Multivariate Non-normally Distributed Random Variables in Climate Research - Introduction to The Copula Approach," Nonlinear Process. Geophys., vol. 15, no. 5, pp. 761-772, 2008.

[4] L. R. Sasongko, "Copula untuk Memodelkan Kegagalan Dua Dimensi pada Produk Bergaransi dengan Strategi Penggantian," Institut Teknologi Bandung, 2014.

[5] Jamilatuzzahro., R. Herliansyah, and R. E. Caraka, Aplikasi Generalized Linear Model Pada R, Yogyakarta: Innosain, 2018.

[6] M. Ginting, Topowijono, and S. Sulasmiyati, "Pengaruh Tingkat Suku Bunga, Nilai Tukar, dan Inflasi terhadap Harga Saham:Studi Pada Sub-Sektor Perbankan di Bursa Efek Indonesia Periode 2011-2015," J. Adm. Bisnis Univ. Brawijaya, vol. 35, no. 2, pp. 77-85, 2016.

[7] A. T. P. Najafabadi, M. R. Farid-Rohani, and M. Qazvini, "A GLM-based Method to Estimate A Copula's Parameter(s)," J. Iran. Stat. Soc., vol. 12, no. 2, pp. 321-334, 2013.

[8] N. L. Arisandi, D. B. Nugroho, and L. R. Sasongko, "Analisis Prediksi IHSG Berdasarkan Kurs Beli IDR-USD Melalui Regresi Copula,” $J$. Mat. dan Apl. deCartesianN, vol. 7, no. 2, p. 59, 2018.

[9] A. Harahap, "Analisis Perbedaan Retrun dan Abnormal Saham Sebelum dan Setelah Pengumuman Right Issue Pada Lembaga Keuangan Yang Terdaftar di Bursa Efek Indonesia,” J. Ekon., vol. 20, no. August, p. 32, 2012.

[10] H. S. Husain, "Distribusi Normal Multivariat," $J$. Mat. Stat. dan Komputasi, vol. 14, no. 2, p. 143, 2018.

[11] L. M. Leemis and J. T. McQueston, "Univariate Distribution Relationships," Am. Stat., vol. 62, no. 1, pp. 45-53, 2008.

[12] T. Thadewald and H. Büning, "Jarque-Bera Test and Its Competitors for Testing Normality: A Power Comparison," 2004

[13] T. W. Anderson and D. A. Darling, "Asymptotic Theory of Certain 'Goodness of Fit' Criteria Based on Stochastic Processes," Ann. Math. Stat., vol. 23, no. 2, pp. 193-212, 1952.

[14] Y.-K. Tse, Nonlife Actuarial Models Theory, Methods and Evaluation. New York: Cambridge University Press, 2009.

[15] C. Genest, B. Rémillard, and D. Beaudoin, "Goodness-of-Fit Tests for Copulas: A Review and A Power Study," Insur. Math. Econ., vol. 44, no. 2, pp. 199-213, 2009.

[16] R. B. Nelsen, An introduction to Copulas (Springer Series in Statistics), 2nd ed. Portland: Springer Science+Business Media, Inc., 2006.

[17] N. Insani, "Penerapan Metode Bagi-Dua (Bisection) pada Analisis Pulang-Pokok (Break Even)," 2006. 
Egidius Saut Poltak Situmorang, Bambang Susanto, Leopoldus Ricky Sasongko

d'Cartesian: Jurnal Matematika dan Aplikasi, Vol. 9, No. 2 (September 2020): 105-112

[18] Hariyanto, L. R. Sasongko, and D. B. Nugroho, "Analisis Kurva Kuantil Bersyarat untuk Data IHSG dan Kurs Beli CNY-IDR," PROSIDINGM9, 2019.

Egidius Saut Poltak Situmorang

(egidiussaut@gmail.com)

Lahir Bekasi, Jawa Barat. Dia masih
menempuh pendidikan tinggi di Program
Studi Matematika, Fakultas Sains dan
Matematika, Universitas Kristen Satya
Wacana (UKSW) Salatiga. Tahun 2020
$\begin{aligned} & \text { adalah tahun terakhir ia menempuh } \\ & \text { studi. Makalah ini merupakan hasil } \\ & \text { penelitian skripsinya } \\ & \text { dipublikasikan. }\end{aligned}$

Bambang Susanto (bambang.susanto@uksw.edu)

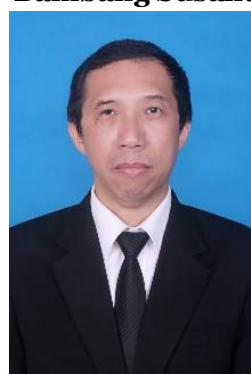

Lahir di Ambarawa, 12 Juli 1963. Lulus sarjana pada tahun 1988 dari Universitas Diponegoro Semarang. Gelar Magister Sain diperolehnya pada tahun 1992 dari Institut Tekonologi Bandung dan Doktor Matematika pada tahun 2005 dari Institut Teknologi Bandung. Sejak tahun 1988, ia bekerja di Universitas Kristen Satya Wacana, Salatiga. Beberapa matakuliah yang diampunya sampai saat ini adalah : Matematika Diskret, Aljabar Linear, Fungsi Kompleks, Geometri Euclid, Statistika Matematika, Komputasi Finansial, Teknik Peramalan dan Analisis Data Multivariat. Bidang penelitian yang diminati adalah time series modeling dan cryptography serta landasan teoritis yang melatarbelakanginya seperti aljabar linear dan matematika diskrit.Berikut dua makalah hasil penelitiannya bersama rekan dosen dan mahasiswa bimbingan: Desain S-Box Fleksibel : Regenerasi Konstanta dan Koefisien Fungsi Linier Berbasis CSPRING Chaos yang dipublikasikan di Jurnal Nasional Teknik Elektro dan Teknik Informatika Vol. 8 No. 1 (2019) dan Modeling of Return Volatility using GARCH(1,1) Model under Tuckey Transformations Jurnal Akutansi dan Keuangan 21(1), Mei 2019, Universitas Petra.

\section{Leopoldus Ricky Sasongko}

(leopoldus.sasongko@uksw.edu)

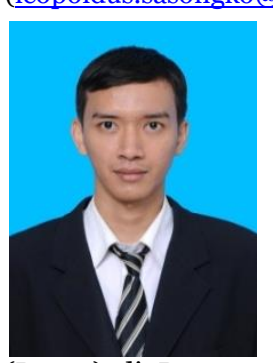

Lahir di Ketapang, Kalimantan Barat, pada tanggal 14 November 1989. Pada tahun 2011, gelar Sarjana Sains (S.Si) diperoleh dari Universitas Kristen Satya Wacana (UKSW) Salatiga. Gelar Magister Sains (M.Si) didapat dari Program Pascasarjana Magister Aktuaria, Institut Teknologi Bandung (ITB), pada tahun 2014.

Ia bekerja di UKSW sejak tahun 2011 sebagai Calon Pengajar Akademik (Dosen) di Program Studi Matematika, Fakultas Sains dan Matematika, UKSW. Saat ini, ia menjadi Pengajar Akademik Tetap di UKSW.

Sasongko, M.Si, merupakan salah satu anggota Asosiasi Matematikawan Indonesia, IndoMS. Bidang penelitian yang digeluti adalah Matematika Aktuaria dan Garansi (Warranty). Salah satu makalah hasil penelitian adalah The Estimation of Renewal Functions Using the Mean Value Theorem for Integrals (MeVTI) Method yang terpublikasi di Jurnal Matematika dan Aplikasi deCartesiaN, Universitas Sam Ratulangi (UNSRAT). 